\title{
THE ROLE OF COMMUNICATION IN SACCOS IN PROMOTING FINANCIAL INCLUSION IN KENYA
}

\author{
Rose Ndegwa ${ }^{\mathrm{i}}$ \\ Meru University, \\ Kenya
}

\begin{abstract}
:
Financial inclusion is a prerequisite to economic development. This has been echoed by international as well as national bodies. Studies have shown that financial exclusion has its roots in social exclusion. This indicates the depth and importance of financial inclusion in creating inclusive development. Numerous studies have revealed levels of financial inclusion with limited studies performed on the role of SACCO initiatives on financial inclusion. This research examined measures of financial inclusion which include both access and usage of financial products by low income earners and the socially excluded via SACCOs. Since access and usage are supplementary, they reflect a more vivid picture of financial inclusion. The study sought to analyze the role of SACCOs in promoting financial inclusion in Kenya. The study was guided by the three specific objectives: geographical coverage of SACCOs; cost and contribution of SASRA regulations towards enhancing financial inclusion. To achieve the objectives of the study a descriptive survey research was adopted. The target population was the three SACCOs in Meru town. 43 questionnaires were issued to SACCO members to access the level of financial service access. Primary data was analyzed with aid Microsoft excel software to generate frequencies, mean and percentages. Pie charts, graphs and tables were used to present various aspects of the variables. Content analysis was used to analyze qualitative while quantitative data was analyzed using descriptive statistics.
\end{abstract}

JEL: O10; O20; G10; G20

Keywords: SACCO, financial inclusion, geographical coverage, deposit taking SACCOS, front office savings activities

\section{Introduction}

Financial inclusion is defined as the process of availing an array of financial services to an individual, household or group at affordable price, at the convenient place, form and

i Correspondence: email gacherirose93@gmail.com 
time without any discrimination to all members of society (FinMark Trust, 2006). The primary objective of inclusion should be advantaging the poor majority who do not have access to formal financial services by alleviating financial exclusion which leads to loss of opportunity to grow, retarded country growth and increase in poverty levels. Further it brings real and rising costs often born by those who can least afford them.

A well-functioning financial system accessible to all reduces information and transaction cost, influences savings rate, investment decisions, technological innovations and spur long term growth rate (Okwany, 2010; Wanyama, 2009). According to United Nations, 2.7 Billion of bankable people around the world do not have access to formal financial services like savings account, credit, insurance and payment service (United Nations, 2007). Although this problem is universal the financially excluded person is in most instances the average citizen in any developing country. In sub Saharan Africa 80 percent of bankable population, 325 million people remains financially excluded with those having access to formal financial services constituting to operating a bank account only.

In Kenya financial inclusion has grown tremendously over the years. Nonetheless it has failed to provide adequate access to banking services to the bulk of population and lending is skewed in favor of large private and public enterprises in urban areas. This is evidenced by distribution of bank branches at 93 percent in urban areas and 7 percent in rural and semi-arid zones (FinAccess, 2009). This demonstrates there are exclusions in poorer sections of society and a lot has to be done to draw more Kenyans into financial system. Data from the ministry of cooperatives, development and marketing shows that SACCOs have been growing at a rate of $25 \%$ per year for the past six years, (Government of Kenya, 2011). This has mainly been driven by the interest rates regime, which has seen the SACCOs charge lower interest than the commercial banks. For instance, when banks were charging $18 \%$ in the year 2011, SACCOs charged interest at between 10-12\% locking out a substantial borrowing pool from the banks. This has driven many salaried people to the SACCOs and has seen the growth of the sector in leaps and bounds.

\section{Problem Statement}

Exact number of SACCOs operating in Kenya is not known, estimates range from almost 4,000 up to 5,000 (Deepening, 2010). SACCOs are capable of distributing opportunities more evenly to poorer households and economically disadvantaged geographical regions. Financial inclusion is an intervention strategy that seeks to overcome the market hindrances that prevent market from operating in favor of poor and underprivileged. The SACCOs come in here by offering incremental and complimentary solutions to tackle poverty, promote inclusive development and address millennium development goals (Chibba, 2009). SACCOs aim at drawing the unbanked population into formal financial system so that they have the opportunity to access financial service ranging from saving, payment, transfer of credit, pension planning and insurance products.

In addition to advancing loans at interest rates lower than other financial service providers, SACCOs have the ability and opportunity to reach clients in areas that are 
unattractive to banks e.g. rural and semiarid areas. The core objective of SACCOs is to ensure members empowerment via mobilization of savings and funds deployment, lending over shillings 200 billion annually (Cooperative bank of Kenya, 2010). SACCOs in Kenya are required to adhere to regulations set in the SACCO regulation authority (SASRA). The management has to present the capital adequacy return reports, liquidity statement report, Statement of financial position and Statement of deposit return as well as Return on investments report which compares financial assets to the SACCO's core capital.

Despite the critical role played by SACCOs on improving welfare of the poor there has been no study that has focused on establishing the contribution of SACCOs to financial inclusion. Previous studies have focused on credit risk management in SACCOs financial performances. Gisemba (2010) undertook a study on the relationship between credit risk management practices and financial performance of SACCOs in Kenya. The study concluded that the management of the SACCOs was involved in the management of the credit risk through standardization process and documentation watch over loan portfolio's degree of concentration and exposure for credit risk management. Kavulya, (2011) carried out a study on effects of corporate governance. Based on empirical studies no studies have been conducted on the role of communication in SACCOS in promoting financial inclusion in Kenya. The current study seeks to fill this gap.

\subsection{General Objective}

The general objective of the study was to establish the role played by SACCOs in drawing the unbanked population into formal financial system.

\subsubsection{Specific Objectives of the Study}

1) To determine the extent to which vast geographical coverage of SACCOs promote financial inclusion.

2) To establish the relationship between low cost of financial services by SACCOs and financial inclusion.

3) To assess the effect of SASRA regulations on SACCOs in promoting financial inclusion.

\subsection{Research Questions}

1) To what extent has the vast geographical coverage of SACCOs promoted financial inclusion?

2) Is there a relationship between SACCOs low cost of financial services and financial inclusion?

3) What is the effect of SASRA regulations on financial inclusion?

\subsection{The Scope of the Study}

The study was carried out at Yetu SACCO Limited, Capital SACCO, and Solution SACCO in Meru County. These SACCOS were selected to study financial inclusion since their membership is composed of the vast and typically excluded people such as small- 
scale tea farmers, dairy farmers, youths and women financial initiatives. Furthermore, these SACCOs are the highly ranked SACCOs societies in Kenya (KUSSCO, 2011).

\section{Research Methodology}

\subsection{Introduction}

This chapter contains the methodology of the research. It is made up of the research design to be used, the target population, research instruments, sample size and sampling procedures, data collection and data analysis.

\subsection{Research Design}

A descriptive research design was adopted for the study. This is because descriptive survey attempts to describe the behavior and characteristics of a subject without influencing it in any way (Bryman, 2001). It is designed to gain more information about variables and provide accuracy within specified ranges of error in a particular field of study and thus such a design will be the most appropriate. Descriptive survey will involve administering a questionnaire to a sample of individuals.

\subsection{Target Population}

The study population involved three SACCOs in Meru town and its three divisions which are actively involved in drawing the tea and coffee farmers into financial system. SACCOS were selected because of their deep market penetration and hence considered to have a grip of financial inclusion activities. The study involved sampling of all the three SACCO divisions in Meru municipality. A target population of 196 members was available.

\subsection{Sampling Procedure}

The study adopted a sampling survey of all the 3 divisions in the area. This is because Israel, 1992 recommends that the population should be sampled when the population is 200 or more. The sample size was 43 SACCO members. The sample size will comprise 4 executives and 39 customers. The sample size for the executives was a census taken based on department while sample size for employees was computed using the following formula.

$$
\mathrm{n}=\mathrm{N} /\left(1+\mathrm{n}(\mathrm{e})^{\wedge} 2\right)
$$

Where:

$\mathrm{n}=$ sample size

$\mathrm{N}=$ population size

$\mathrm{e}=$ permitted error

$\mathrm{N}=192$

$\mathrm{e}=10 \%$

$\mathrm{n}=192 /\left(1+(0.1)^{\wedge} 2\right)$ 
$\mathrm{n}=43$ members

Table 1: Sample Size for Executives

\begin{tabular}{lcc}
\hline Department & Population & Sample Size \\
\hline Finance and audit & 1 & 1 \\
Credit & 1 & 1 \\
Marketing & 1 & 1 \\
Operations & 1 & 1 \\
\hline Total & 4 & 4 \\
\hline
\end{tabular}

Source: Author, 2014.

\subsection{Data collection}

The researcher used both primary and secondary data; questionnaires were used to gather primary information from the field. The questionnaire comprised the closed and open-ended questions. Open ended questions were used to encourage the interviewee to provide an extensive and developmental answer. For more objective and specific answer closed ended questionnaire were administered. Secondary data was obtained through desk research from internal and external sources. The external sources included publications, reports, newspapers and libraries. Forty three questionnaires were issued to the 4 SACCO heads of departments and 39 members in the 3 divisions.

\subsection{Reliability and Validity}

\subsubsection{Reliability}

Reliability is the extent to which a questionnaire, test, observation or any measurement procedure produces the same results on repeated trials (Miller, 2009). It is the stability or consistency of scores over time or across raters. Reliability co-efficient was be obtained by correlating the scores of odd numbered statements with the score of even numbered statement in questionnaire. The researcher used test-retest to ascertain the coefficient of internal consistency or reliability. The instrument will be administered twice to the same group of subjects at an interval of two weeks.

\subsubsection{Validity}

Validity refers to the extent which an instrument does the measurement of what it is supposed to measure (Kothari, 1985). It can also refer to the extent to which the results of analysis of data from the given phenomenon of study are representative. The validity in the study was enhanced through the appraisal and verification of tools by the supervisor who is an expert. The questionnaire was also made subject to a thorough test and retest procedures with examination of my supervisor whereby any improvements necessary were incorporated. The validity of the content in the study was enhanced through comparison with specific benchmarks.

\subsection{Data Analysis}

Data analysis is the coding, categorizing, data entry, manipulation and summarization of data (A. Mugenda, 2003). The filled questionnaires were checked cleaned and edited to 
ensure that they are correctly and completely filled. Qualitative data generated was analyzed using descriptive statistics such as frequencies and percentages. The data collected was analyzed using descriptive statistics. This includes tables, bar charts pie charts and percentages.

\section{Data Analysis and Interpretation}

\subsection{Introduction}

This chapter presents the findings of the study and their discussion in relevance to the objectives and past studies carried out in same area. Quantitative data was analyzed using Microsoft Excel in the form of frequencies, means, modes and percentages. Qualitative data was presented by content analysis. Presentation was done using tables, charts and graphs for easy yet effective communication. Data analysis aimed to answer the following questions

1) To what extent has the vast geographical coverage of SACCOs promoted financial inclusion?

2) Is there a significant contribution of SACCOs low cost of financial services to financial inclusion?

3) How has the SASRA regulations promoted financial inclusion?

\subsubsection{Response Rate}

The researcher administered questionnaire to 43 members of Yetu SACCO 4 of them being heads of the 3 SACCO divisions and 38 SACCO members. From the 42 questionnaires issued only 1 was not answered. This accounts for a response rate of 97.6 percent which is a representative of the whole population and therefore can be relied on for analysis in this study.

\subsection{Respondent Profile}

The researcher collected background data of the SACCO members. This was in order to establish the characteristics of the people being excluded. These include gender, age, and level of education.

\subsubsection{Age of SACCO Members}

The researcher sought to find out the age of various customers of SACCO who were respondents in the study.

Table 2: Age of Respondents

\begin{tabular}{lcc}
\hline Age & Number of Respondents & Percentage \\
\hline $18-25$ & 4 & 9.6 \\
$26-35$ & 14 & 33.3 \\
$36-45$ & 18 & 42.8 \\
$46-55$ & 4 & 9.5 \\
56 And Above & 2 & 4.8 \\
\hline Total & 42 & 100 \\
\hline
\end{tabular}


Findings in table 2 indicate that most $(42.8 \%)$ of the members of SACCO were aged between 36yrs and 45yrs. This shows that major part of SACCO banking is operated by middle age population.

\subsubsection{Gender of SACCO Clients}

The researcher sought to find out the gender of various members who were respondents in the study.

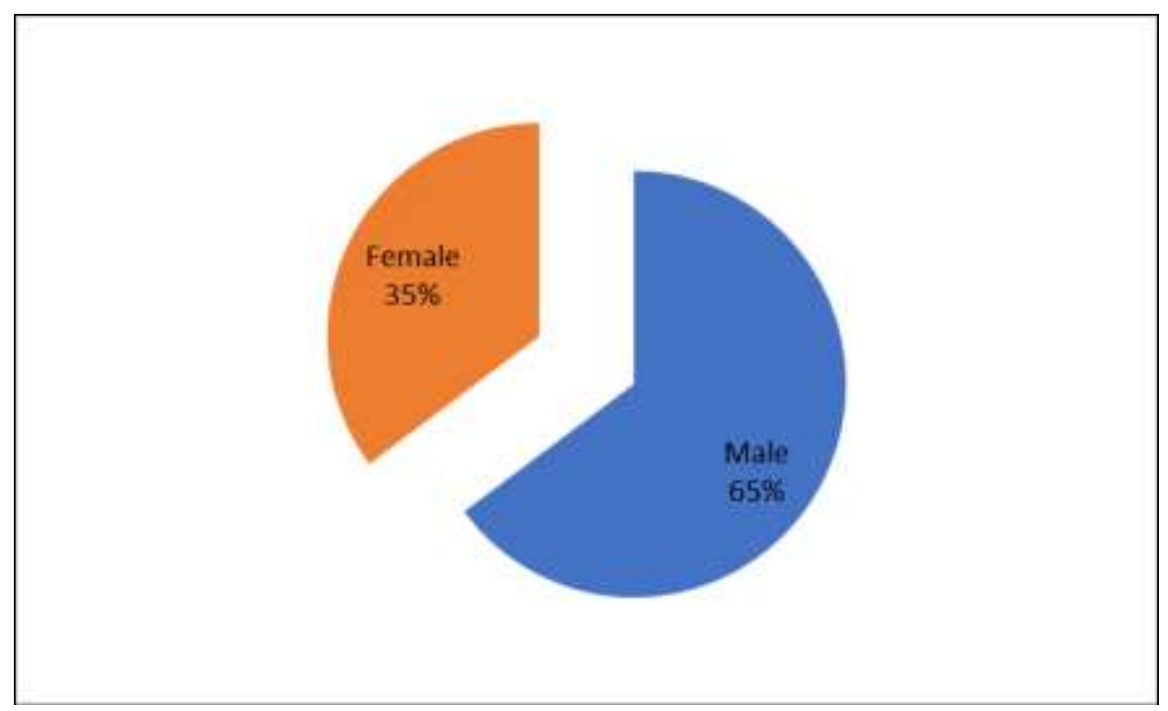

Figure 1: Gender of Respondents

The findings in figure 1 indicate that majority (65\%) of SACCO clients were of male gender and $35 \%$ were female. The findings point to a gender inequality which is a rampant issue among the middle-class communities in Kenya. The findings are in agreement to findings by (UN Habitat, 2003) which found that approximately $70 \%$ of women are socially excluded and financial exclusion is the root cause of social exclusions.

\subsubsection{Level of Education of SACCO Members}

The researcher sought to find out the highest academic qualification achieved by various SACCO members who were the respondents in the study.

Findings in figure 2 indicate that majority (43\%) of SACCO members had a diploma certificate as their highest level of education. This shows that majority of the people who are banking with SACCOs have general understanding of information concerning SACCOs sought by the study. However, for the SACCO executive section all had bachelor's degree. 


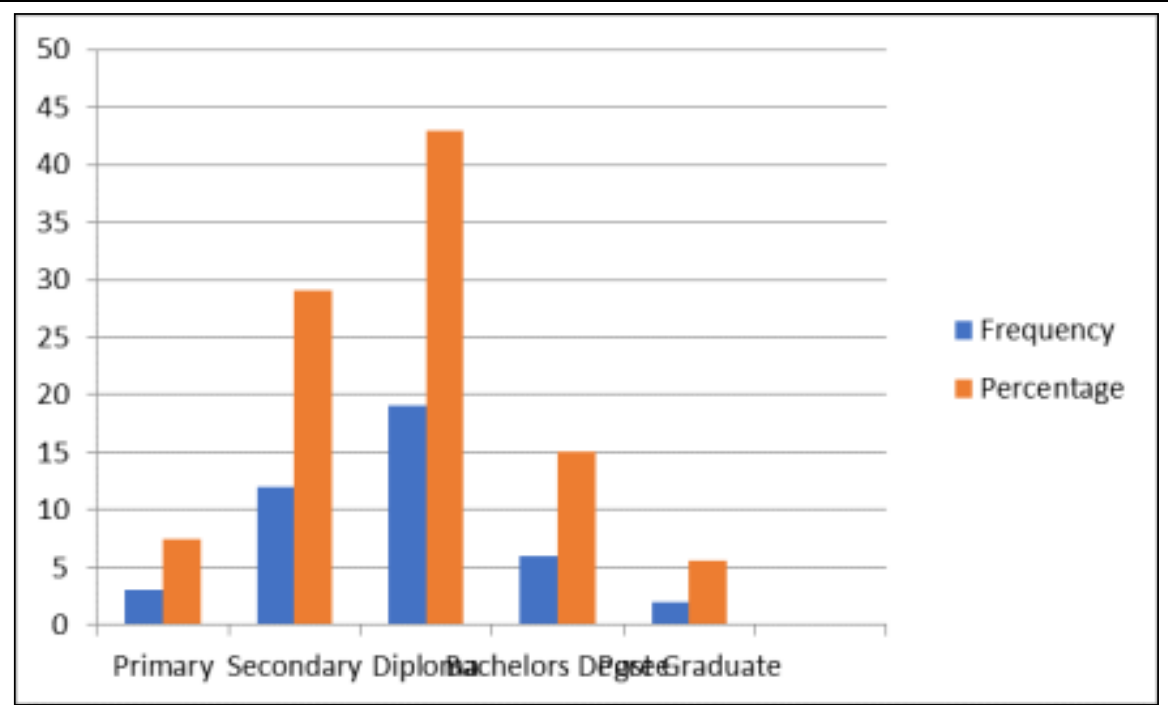

Figure 2: Level of SACCO members Education

\subsubsection{SACCO Members Income Level}

The researcher sought to find out the income levels of SACCO members who were respondents in the study.

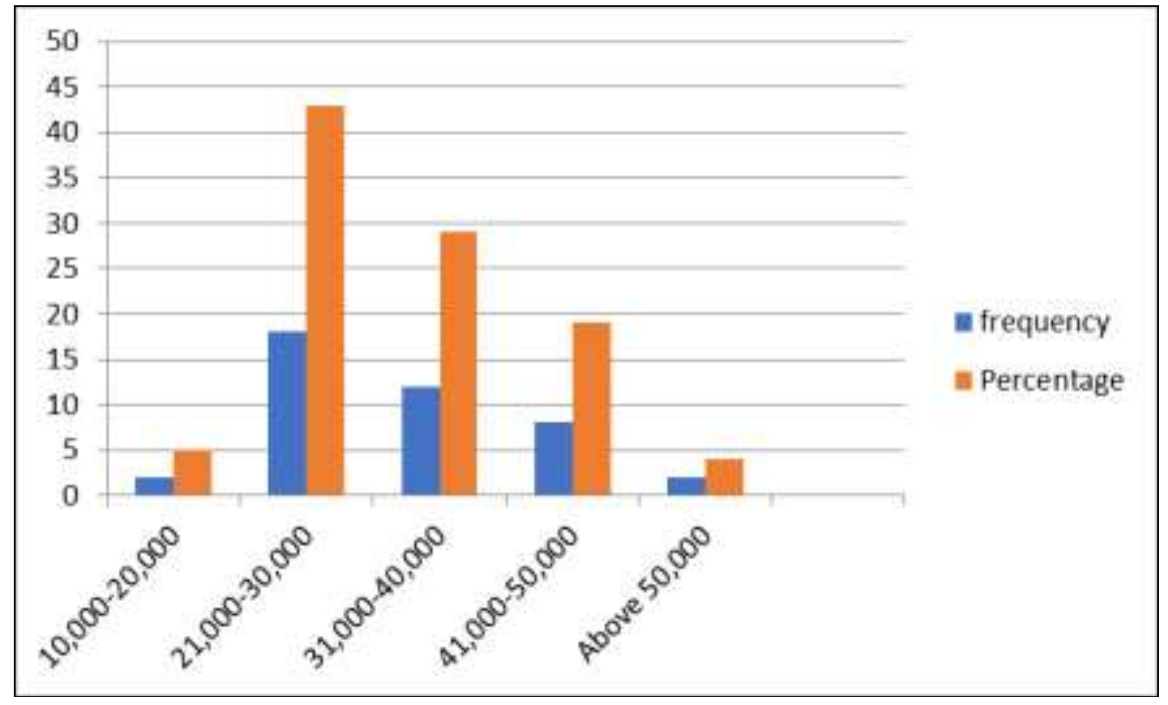

Figure 3: Income level of SACCO members

The findings in figure 3 indicate that majority (43\%) of SACCO members income level lies between 21000 and 30000 shillings. When commercial banks increased their minimum account balances in the 1990s this income bracket was locked out of financial system.

\subsubsection{Marital Status of SACCO Members}

The researcher sought to find out the marital status of SACCO members who were respondents in the study. 


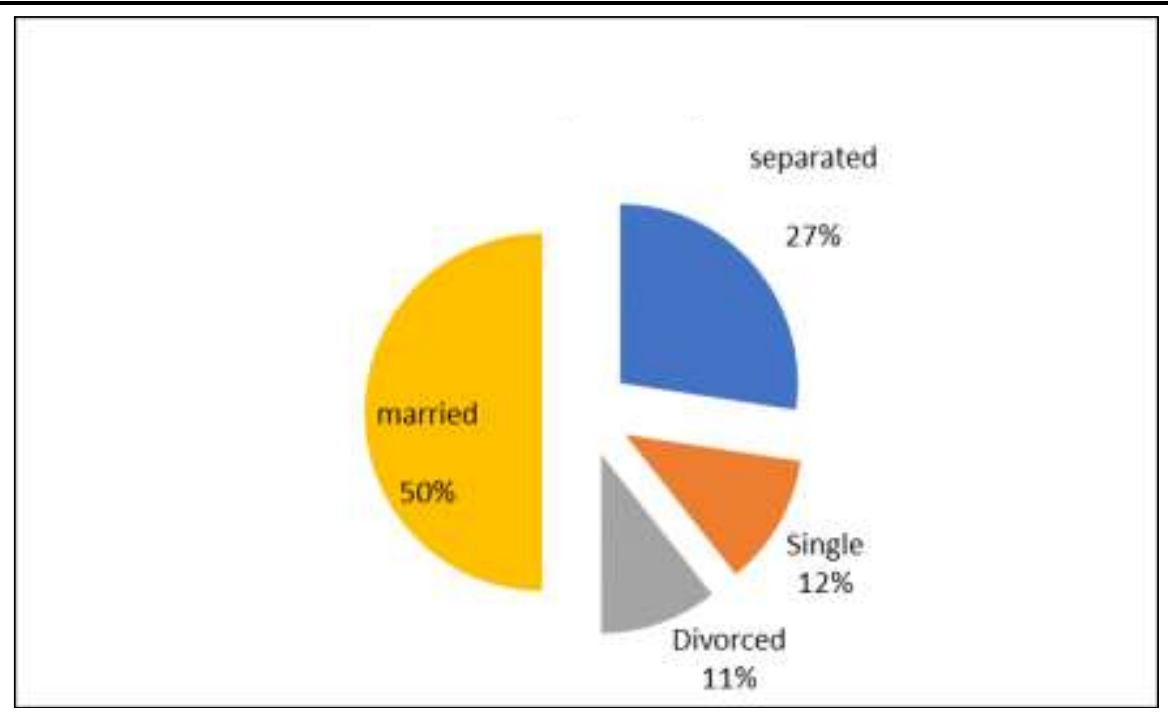

Figure 4: Marital status of SACCO members

Findings in figure 4 reveal that majority (50\%) of SACCO members were married. This shows married people sought financial services to plan their lives and that of their children e.g. pension.

\subsection{Financial Inclusion}

The purpose of this study was to evaluate the role of SACCO in promoting financial inclusion in Kenya. Financial inclusion was measured by the number and frequency of transactions as well as number of accounts opened via SACCOs. As such the researcher sought to find out these details from both SACCO members and managers.

\subsubsection{Commonly used Service}

The researcher sought to find out what banking service was most sought by customers at SACCOs outlets.

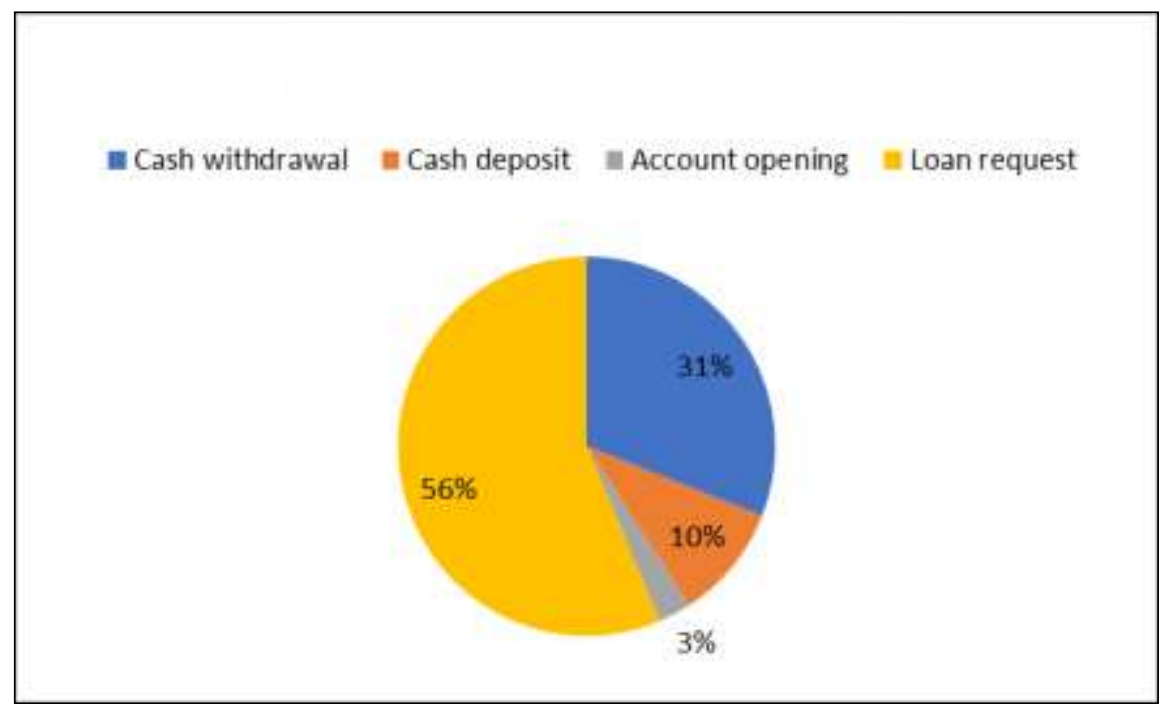

Figure 5: Commonly used service 
According to majority (56\%) of SACCO members' cash withdrawal was the most popular banking service sought by customers.

\subsubsection{Number of Accounts opened in a Day}

The researcher sought to establish the number of accounts opened at the SACCO branches from branch managers.

Table 3: Number of accounts opened

\begin{tabular}{lccccccc}
\hline Statement & none & $\mathbf{2 0}$ and below & $\mathbf{2 1 - 3 0}$ & $\mathbf{3 1 - 4 0}$ & $\mathbf{4 1 - 5 0}$ & Above 51 & Total \\
\hline Number of accounts opened & 0 & 1 & 2 & 1 & 0 & 0 & 4 \\
\hline
\end{tabular}

Findings in table 3 indicate that most (2) of SACCO opened between 21-30 accounts for customers. This shows that account opening was a highly sought service by customers. These findings depict the high rate of financial inclusion activities by SACCOs since it is measured via number of accounts opened and financial service usage.

\subsection{Effect of SACCO Banking on Financial Inclusion}

The researcher sought to find out from bank branch manager the extent to which SACCOs induce financial inclusion.

Table 4: Effect of SACCO banking on financial inclusion

\begin{tabular}{lcc}
\hline Effect & Frequency & Percentage \\
\hline Great extent & 3 & 75 \\
No extent & 1 & 25 \\
Low extent & 0 & 0 \\
\hline Total & 4 & 100 \\
\hline
\end{tabular}

Majority (75\%) indicated that SACCOs had a high effect on financial inclusion.

\subsection{Effect of Geographical Coverage on Financial Inclusion}

This section presents findings related to the first objective of study sought to find out the extent to which geographical coverage of SACCO has promoted financial inclusion.

\subsubsection{Closeness of SACCOs to Customers}

The researcher sought to find out from SACCOs whether closeness to customers had an impact on the number of services sought.

Table 5: Closeness of SACCOs to customers

\begin{tabular}{lcc}
\hline Response & Frequency & Percentage \\
\hline Agree & 32 & 76.2 \\
Neutral & 6 & 14.2 \\
Disagree & 4 & 9.6 \\
\hline Total & 42 & 100 \\
\hline
\end{tabular}


Majority (76.2\%) of SACCO members agreed that some customers prefer SACCOs because they are closer to them as compared to commercial banks. Geographical coverage is one the strengths of SACCOs as services offered by banks are brought closer to the people. These findings are in agreement with previous studies which found that SACCO banking has enabled bank customer to access the SACCOS within comfort of their neighborhoods (Musau, 2013).

\subsubsection{Reduction of Overcrowding in Banking Halls}

The researcher sought to find out from the managers whether greater geographical coverage of SACCOs had reduced overcrowding in banking halls All $(n=4)$ managers agreed that SACCOs reduce overcrowding because more people are utilizing SACCOs since they get served faster.

\subsubsection{Time Taken to Access Financial Service}

The researcher sought to find out the time taken by SACCO members to access financial services at the SACCO outlet.

Table 6: Time taken to access service

\begin{tabular}{lcc}
\hline Time Taken to Bank & Frequency & Percentage \\
\hline Below 10 Min & 35 & 83 \\
11-15 Min & 5 & 12 \\
Above 15 & 2 & 5 \\
\hline Total & 42 & 100 \\
\hline
\end{tabular}

Majority $(83 \%)$ of SACCO clients took below ten minutes to get served at SACCOs. This is because SACCOs generally have fewer clients compared to commercial banks. Further most SACCOs today have adopted modern technologies which speed up and simplify work.

\subsubsection{Distance Travelled by Customers to Access SACCOs}

The researcher sought to find out the distance travelled by SACCO members to access financial services at the nearest SACCO outlet.

Most of the members indicated that they travelled between two and five kilometers to access the nearest SACCO outlet and get served. These points to the vast geographical coverage of SACCOs in Kenya. 


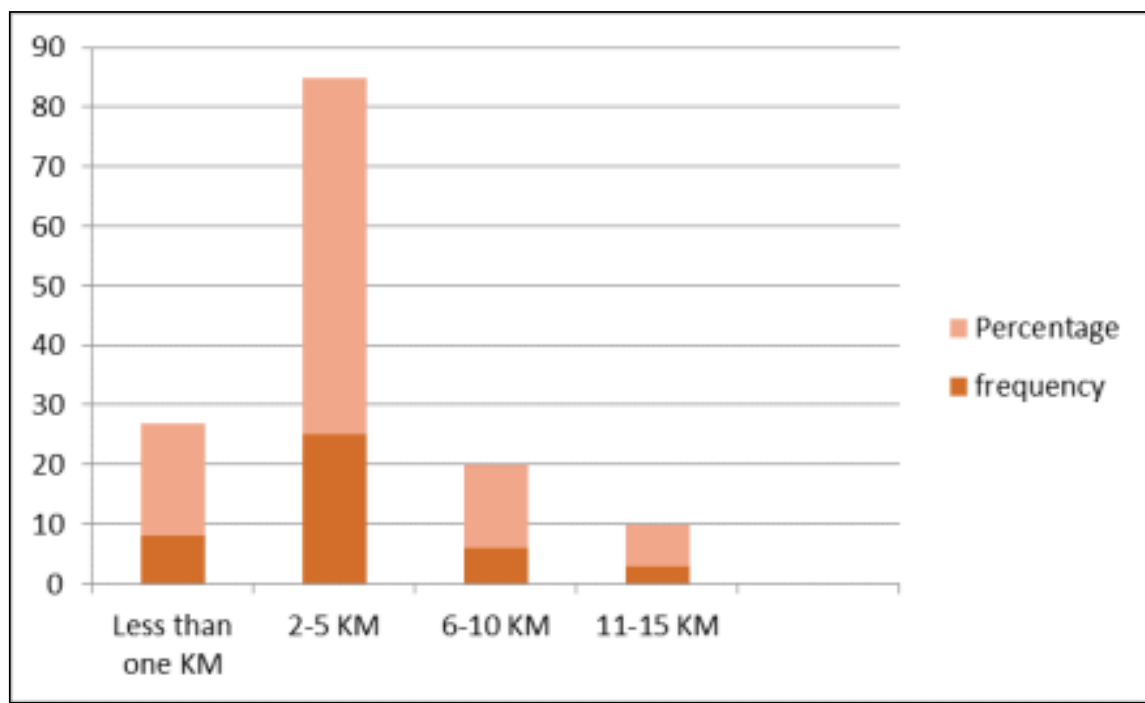

Figure 6: Distance travelled to access service

\subsubsection{Effect of Geographical Coverage of SACCOs on Financial Inclusion}

The study sought to establish the extent to which geographical coverage of SACCOs has promoted financial inclusion. The information was sought from SACCO branch managers. All $(n=4)$ managers agreed that geographical coverage of SACCOs had promoted financial inclusion. This can be attributed to the fact that through SACCOs bank services are brought closer to customers both bank and non-bank. These findings are in agreement with Invatury and Timothy, 2006 who found that SACCOs benefitted clients in the following ways lower transaction cost (proximity), longer opening hours, shorter lines, more accommodative of illiterate and poor who are intimidated by marble banking halls.

\subsection{Impact of Cost at SACCOs on Customer Seeking Financial Service}

The researcher put forward several statements related to costs of services at the SACCO offices.

Table 7: Impact of cost on customer seeking service

\begin{tabular}{lccccc}
\hline Statement & $\begin{array}{c}\text { Strongly } \\
\text { agree }\end{array}$ & Agree & $\begin{array}{c}\text { Strongly } \\
\text { disagree }\end{array}$ & Disagree & Total \\
\hline $\begin{array}{l}\text { Customers prefer SACCOs } \\
\text { regardless of cost }\end{array}$ & 1 & 30 & 2 & 9 & 42 \\
$\begin{array}{l}\text { Customers perceive SACCO } \\
\text { banking to below }\end{array}$ & 28 & 11 & 1 & 2 & 42 \\
\hline
\end{tabular}

Findings in table 7 indicate that majority (34) of operators of SACCO outlets agreed that customers perceive the cost of banking with SACCOs to be low. However, despite this perception customers prefer to use SACCOs regardless of costs charged as indicated by majority of customers. This shows that even though charges at SACCOs were higher some customers still preferred to use them for banking needs. This can be attributed to other benefits of SACCOs such as nearness to customers. 


\subsection{Effect of Cost of Service on Financial Inclusion}

The researcher sought to find out from SACCO branch managers on the impact of cost of service on financial inclusion.

Table 8: Effect of cost of service on financial inclusion

\begin{tabular}{lcc}
\hline Effect & Frequency & Percentage \\
\hline Great Extent & 3 & 75 \\
No Effect & 0 & 0 \\
Low Extent & 1 & 25 \\
\hline Total & 4 & 100 \\
\hline
\end{tabular}

Majority (75\%) of SACCO branch managers indicated that cost of service had great effect on financial inclusion. This can be attributed to the fact that majority of customers were low income earners and depend much on loans. These findings are in agreement with past studies which found that the cost of financial services in commercial banks was a deterrent to customers. (Mussau, 2013).

\subsection{SASRA Regulation}

This section presents findings related to the third objective of the study which sought to find out the effect of SASRA regulation on financial inclusion.

\subsubsection{Maximum and Minimum Cash Limits}

The researcher sought to find out from SACCO branch managers whether SASRA authorities dictated maximum and minimum cash limits they should hold. All $(n=4)$ of the branch manager confirmed that the SASRA regulations had dictated minimum limits for operation function. This is because liquidity is important to satisfy the needs of the customers. If customers cannot withdraw or access loans because the SACCO doesn't have enough cash the SACCO model is bound to fail.

\subsubsection{Customer Confidence}

The researcher sought to find out from SACCO members whether SASRA regulations had boosted customer confidence in SACCOs.

Table 9: Customer confidence

\begin{tabular}{lcc}
\hline Effect & Frequency & Percentage \\
\hline Strongly Agree & 3 & 7 \\
Agree & 33 & 78.1 \\
Disagree & 4 & 10 \\
Strongly Disagree & 2 & 4.9 \\
\hline Total & 42 & 100 \\
\hline
\end{tabular}

Majority $(78.1 \%)$ indicated that lack of SASRA regulations makes customers lose confidence in SACCOs and stay locked out of financial service playground. These findings are in agreement with financial sector deepening trust report (FSDT, 2012) which 
has shown remarkable upward trend in SACCO subsector confidence since inception of SASRA.

\subsubsection{Quality of Service}

The researcher sought to find out from SACCO customers whether quality of financial services has increased since inception of SASRA.

Table 10: Quality of service

\begin{tabular}{lcc}
\hline Response & Frequency & Percentage \\
\hline Strongly Agree & 5 & 12 \\
Agree & 34 & 81 \\
Disagree & 2 & 5 \\
Strongly Disagree & 1 & 2 \\
\hline Total & 42 & 100 \\
\hline
\end{tabular}

Majority (81\%) agreed that quality of service has improved since SASRA regulations were enacted. This has boosted the image of SACCOs hence financial inclusion.

\subsection{Frequency of Cash Shortages}

The researcher sought to find out from SACCO branch managers the frequency of cash shortages in SACCOs. All $(n=4)$ branch managers indicated that shortage of cash has not been reported since inception of SASRA regulations. This points to effectiveness of SASRA regulations in ensuring financial soundness of SACCOs.

\subsection{Effect of SASRA Regulation on Financial Inclusion}

The researcher sought to find out from SACCO branch managers whether SASRA regulations had any impact on financial inclusion. All $(n=4)$ agreed that SASRA regulations had positively affected financial inclusion. This is deduced from ongoing growth in numbers in leaps and bounds. Financial unsoundness of one SACCO has adverse effect on all others since customers evaluate confidence in financial sector as a whole.

\subsubsection{SASRA Licensing}

The researcher sought to find out from SACCO branch managers whether Yetu SACCO was licensed by SASRA. All $(n=4)$ agreed that the SACCO was licensed and therefore legally operated the FOSA services. This showed the researcher that the SACCO executives were in a position to understand the information sought by the study relating to effect of SASRA on financial inclusion.

\subsubsection{Factor with Greatest Effect on Financial Inclusion}

The researcher sought to find out from SACCO branch managers which variable had the greatest effect on financial inclusion. All $(n=4)$ branch managers agreed that geographical coverage had the greatest effect on financial inclusion. This was attributed to vast coverage of SACCOs and rarity of commercial banks in rural areas. 


\section{Summary, Discussions, Conclusions and Recommendations}

\subsection{Introduction}

This chapter presents a summary of findings from data collected during the study. It further presents discussions on the findings and the researchers' conclusions and recommendations.

\subsection{Summary of the Findings}

It is clear from the theoretical and empirical literature that majority of the world's population is financially excluded. This financial exclusion is a subset of social exclusion. Those financially excluded cannot participate in social and economic activities of the country leading to inequality which breeds many other vices. It is only through deliberate effort on social inclusion like financial inclusion that all can be brought to the economic playground of the country. Care though should be taken to address the issue of financial inclusion expeditiously to avoid creating financial instability. The role of SASRA regulations should also be carefully defined as studies show excess intervention from government can yield more harm than good. Proper banking models should be designed with appropriate products as the benefits of financial inclusion are immense.

\subsubsection{Effects of Geographical Coverage on Financial Inclusion}

On the effect of geographical coverage of SACCOs on financial inclusion, the study found that majority (75\%) of customers agreed that they prefer SACCOs because they are closer to them as compared to main bank. All $(\mathrm{N}=4)$ the SACCOs branch manager in the study confirmed that SACCOs had reduced overcrowding in banking halls saving customers time. All the four branch managers agreed that SACCOs had promoted financial inclusion.

\subsubsection{Cost of Services and Financial Inclusion}

On the effect of SACCOs cost of service on financial inclusion the study found that costs of accessing services at SACCOs were less compared to commercial banks. Majority $(63 \%)$ of SACCOs members agreed that they perceive cost of banking with Sacco's to be low. However, despite this perception, customers prefer to use SACCOs regardless of cost charged as indicated by majority (75\%) of the customers. Majority of SACCOs managers indicated that cost of services at saccos had great effect on financial inclusion.

\subsubsection{SASRA Regulation and financial Inclusion}

On the effect of SASRA regulations on financial inclusion the study found that all $(n=4)$ of branch managers confirmed that SASRA authorities had dictated cash limits that the SACCOs could hold. Majority (78\%) of the SACCOs customers agreed that SASRA regulations had boosted their confidence in SACCOs unlike before regulations were enacted. Quality of financial services by SACCOs has been trending skywards due to effectual supervision and disclosures by SASRA authorities and publications. This is 
according to majority of SACCOs customers. All (75\%) of managers agreed that SASRA regulations affected financial inclusion to a great extent.

\subsection{Discussion}

In this section the findings of the study are discussed and related to the findings in the literature review as per objective.

\subsubsection{Geographical Coverage and Financial Inclusion}

The study found that SACCOs had brought banking services closer to the people. The increase of accounts opened through SACCOs can be attributed to the closeness of banking services to the residential and business premises. Prior to introduction of SACCO model in Meru county customers had to physically present themselves at the banking halls to make all transactions. The disadvantage of this is that there was very long queues' leading to time wastage. Saccos today have been able to decentralize this process allowing customers to open accounts, make deposits and withdrawals within the comfort of their residential areas. These findings are in agreement with Invatury and timothy (2006) who found that SACCOs benefited clients in the following ways ; lower transaction cost (closer to client home), longer opening hours, shorter lines than in commercial banks, more accessible for illiterates and the very poor who might feel intimidated in marble bank outlets.

\subsubsection{Cost of Service and Financial Inclusion}

The study established that cost of services at SACCOs were lower than costs at commercial banks. Findings further reveal that SACCOs are financially attractive to them regardless of costs. These findings are in agreement with Musau (2012) who in a study concerning cost in commercial banks revealed that cost of finance was a deterrent to more customers using financial products. Customers would prefer SACCOs regardless of costs because of other benefits attributed to SACCOs such as close proximity to customers. Low costs have increased financial inclusion in terms of usage of products.

\subsubsection{SASRA Regulation and Financial inclusion}

The findings of this study reveal that SASRA regulations have led to improvement of quality of financial services since their inception. Customer confidence has also been boosted by SASRA regulations. This is partly due to stringent requirements for liquidity management and disclosure of inside financial information to members who are able to take action incase collapse is imminent. If problems of liquidity recur, customers may lose confidence in SACCOs creating a barrier to financial inclusion. These findings are in agreement with financial sector deepening researchers. (SASRA, 2014).

\subsection{Conclusions}

The study concludes that financial inclusion intervention measure should continue, the array of products that make up financial inclusion should be identified, provided and 
diversified. Proper measures of financial inclusion which include both access and usage should be applied, since access and usage are not the same but supplementary.

\subsubsection{Geographical Coverage and Financial Inclusion}

SACCOs have brought banking services closer to the people; in this way SACCOs promote financial inclusion. This is evidenced by fact that customers were willing to forego the extra cost of financial service should any arise at SACCOs. Therefore, geographical coverage is a significant driver of financial inclusion.

\subsubsection{Costs of Service and Financial Inclusion}

Although costs at SACCOs may be higher than for example services at Automated Teller Machines, this did not deter customers from utilizing SACCOs. This could be attributed to the fact that SACCOs bring services closer to the people and they are convenient (faster than commercial banks).

\subsubsection{SASRA Regulation and Financial Inclusion}

SASRA regulation promotes financial inclusion in that cash shortages were rare, managers with relevant qualifications performed proper financial stewardship roles. This builds customers confidence in the SACCO model thereby increasing access to banking services to more people.

\subsection{Recommendations}

This study recommends that more studies should be conducted to measure the impact of financial inclusion interventions in Kenya as currently what is there is different studies with different results. The study to be conducted should analyze the banking models used so that the best models can be applied to achieve full financial inclusion in Kenya by the year 2030 .

Studies on informal financial services should be done as they continue to thrive despite the financial inclusion initiatives and their exorbitant costs, thievery and unreliability.

\subsubsection{Geographical Coverage and Financial Inclusion}

More SACCO outlets should be opened to enhance deeper penetration into rural areas. This will ensure more convenience to the existing and potential customers since $55.5 \%$ of the 19 million bankable populations are still out of financial service orbit.

\subsubsection{Cost of Service and Financial Inclusion}

Given that one of the major reasons for introducing SACCOs was to provide a delivery channel for offering financial services in a cost effective manner, SACCOs should always ensure a limit on their operational costs to avoid the cost of financial services to the customer going up. 


\subsubsection{SASRA Regulation and Financial Inclusion}

As the SACCOs become popular SASRA authorities have to be extra careful about the conduct of SACCOs they license and ensure they uphold the required standards of delivery. This is because in case one major SACCOs collapses customers allover lose confidence in entire SACCO subsector and prefer to be out of financial services.

\subsection{Suggestions for Further Study}

The current study evaluated the role of SACCOs in promoting financial inclusion in Kenya. However, the study was limited to Meru town which is a small area as compared to the rest of the republic. The researcher recommends duplication of the current study in a large area perhaps an entire country.

Research can also be conducted on the financial stability of SACCOs to ensure that SACCO institutions create a sustainable network of agents. This is important since it will increase accessibility and customer confidence.

Future research should also analyze the cost benefit analysis of implementing SACCO model as this will help identify areas where financial institutions can reduce cost and improve banking process.

This study also recommends that a further study should be carried out to determine the challenges facing SACCOs in implementation of financial inclusion activities

\section{References}

A. Mugenda, M. A. (2003). Research Methods: Qualitative and Quantitative Approach. Nairobi: University of Nairobi.

Alila P. \& Obando, P. (1990). Cooperative Credit: The Kenyan Saccos in a Historical and Development Perspective. Nairobi: Oxford university press.

Bagehot, W. (1873). A Description of Money Market. London: Yale university.

Chibba (2009). Financial Inclusion, Poverty Reduction and the Millennium Development

Goals. European Journal of Development Research, 213-220.

Deepening, F. S. (2010). Financial Inclusion in Kenya. Nairobi: FSD Kenya.

Demirguc-kunt, T. B. (2008). Finance for All? Policies and Pitfalls in Expanding Access. Washington D.C: World Bank.

Demsetz (2002). Ownership Structure and Corporate Performance. Journal of Corporate Finance, 209-233.

Diamond, D. (1984). Financial Intermediation and Delegated Monitoring. Review of Economic Studies , 393-414.

F. O., W. (2007). The impact of liberalization on the cooperative movement of Kenya. Finance, 20-26.

Fin Access (2009). Financial Sector Deepening. Nairobi: Princeton University.

Gardeva, A. \&. (2011). Opportunities and Obstacles to Financial Inclusion. McGraw-Hill Book Company. 
Goldsmith, R. (1969). Financial Structure and Development. Washington D.C: Yale University Press.

Inclusion, A. F. (2012). Banking in Latin America. AFI Press.

J. A., O. (2003). Techniques of Writing Research Proposals and Reports in Education and Social Sciences. Nairobi: Masola Publishers.

J. Waksberg (1999). The Role of Sampling in Population Census: Its Role in Accuracy and Timeliness.

Jensen, M. (1976). Value maximization, Stakeholder Theory and Corporate Objective Function. Journal of Applied Corporate Finance, 3305-3360.

Kattambo, V. (1992). Cooperatives, Formation, Management and Settlement of Disputes. London: Oxford University Press.

Kenya, G. O. (2013). Annual Report. Nairobi: Government printers.

M. Serrao, A. S. (2012). Designing a Methodology to Investigate Accessibility and Impact of Financial Inclusion. Washington D.C: Brookings Institution.

N. Ndungu (2010). Policies for Prosperity. London: Oxford University Press.

Nation, U. (2007). Best Practices for Financial Inclusion. Chicago: UN Department of public Information.

Ndebbio, J. (2004). Financial Deepening, Economic Growth and Development. Nairobi: Focus publishers.

Orodho, J. (2003). Techniques of Writing Research Proposals. Nairobi: Masola Publishers.

Pickens, I. J. (2006). Low Income Customers. Washington D.C: Vodafone Group Foundation.

Stefan. (2010). The Banking Agent Reform in Kenya. Boston: Harvard University Press.

Trust, F. (2006). Making Financial Market Work for the Poor in South Africa. Cape Town: Finscope.

Wainaina (2011). Agency Banking to Drive Financial Inclusion in Kenya. Nairobi: University of Nairobi. 

distribute, transmit or adapt the article content, providing a proper, prominent and unambiguous attribution to the authors in a manner that makes clear that the materials are being reused under permission of a Creative Commons License. Views, opinions and conclusions expressed in this research article are views, opinions and conclusions of the author(s).Open Access Publishing Group and European Journal of Economic and Financial Research shall not be responsible or answerable for any loss, damage or liability caused in relation to/arising out of conflict of interests, copyright violations and inappropriate or inaccurate use of any kind content related or integrated on the research work. All the published works are meeting the Open Access Publishing requirements and can be freely accessed, shared, modified, distributed and used in educational, commercial and non-commercial purposes under a Creative Commons Attribution 4.0 International License (CC BY 4.0). 